\title{
Novel Techniques in the Production of Industrially Imperative Products
}

\section{Sameera V}

Biotechnology Department, REVA Institute of Science and Technology, Bangalore University, India

\begin{abstract}
The products which are being developed by the biotechnology industry have huge implications for our future health and well-being. All these discoveries in current biotechnical research and its applications will have repercussions within the human history. In recent years, microbial fermentations have been revolutionized by the application of genetically-engineered microorganisms. Economic importance of bacteria describes mainly from the fact that they are extensively exploited by humans in a number of beneficial ways. Fermentation is one such phenomenon in which micro organisms like bacteria, fungi, algae, etc are utilized for production of novel products. Industries like, diary, food, textile, baking etc are most benefited by these fermented products. Present article mainly focuses on the recent techniques which are involved in enhanced production of imperative products like lactic acid, cellulase, Human interferon $\alpha$, and exopolysaccharide, and advantages of fermentation technology.
\end{abstract}

Keywords: Fermentation; Product purification; Inoculums; Bioreactor; Metabolome; Recombinant proteins; Crystallization.

Abbreviations: Mab: Monoclonal antibodies; SCP: Single Cell Protein; VRICR: Vertical Rotating Immobilized Cell Reactor; CBH: Cello biohydrolases; NTG: N-nitrosoguanidine; EPS: Exopolysaccharides; PLLA: Poly-L-Lactic acid

\section{Introduction}

Microorganisms are capable of growing on a wide range of substrates and can produce a remarkable spectrum of products. The relatively recent advent of in vitro genetic manipulation has extended the range of products that may be produced by microorganisms and has provided new methods for increasing the yields of existing ones. The commercial exploitation of the biochemical diversity of microorganisms has resulted in the development of the fermentation industry and the techniques of genetic manipulation have given this well-established industry the opportunity to develop new processes and to improve existing ones. The term fermentation is derived from the Latin verb fervere, to boil, which describes the appearance of the action of yeast on extracts of fruit or malted grain during the production of alcoholic beverages. However, fermentation is interpreted differently by microbiologists and biochemists. To a microbiologist the word means any process for the production of a product by the mass culture of microorganisms. To a biochemist, however, the word means an energy-generating process in which organic compounds act as both electron donors and acceptors, that is, an anaerobic process where energy is produced without the participation of oxygen or other inorganic electron acceptors [1].

Nowadays there is an increase in interest in the development of more efficient and less time consuming methods to measure the presence of microorganisms, as well as their viability for bioprocess control and improvement [2]. Identification of specific micro organisms is very important for carrying out fermentation process [3].

The manufacture of industrially important products by the methods of modern biotechnology is separated into two stages: upstream processing during which proteins are produced by cells genetically engineered to contain the desired gene which will express the product of interest and downstream processing during which the produced products are isolated and purified [4] (Figure 1).

\section{Upstream processing}

Today, upstream processing can also take place in whole animals or plants, making the animal or plant a genuine bioreactor.

E.g. Monoclonal antibody (Mab) production using mice.

Other protein pharmaceuticals have been produced in the milk of goats and sheep and the leaves of tobacco to mention a few instances of this sort of upstream production of proteins [4].

Upstream processing may involve steps like preparation of inoculums, scaling up, inoculating the inoculums in the culture media/ reactor, assessment of qualitycontrol periodically during various steps of fermentation, controlling of $\mathrm{pH}$, temp, etc. (Figure 2) [4].

\section{Downstream processing}

In a biochemical process, the highest operating and equipment costs can often be found in the area of downstream processing [5]. Downstream processing mainly refers to the recovery and purification

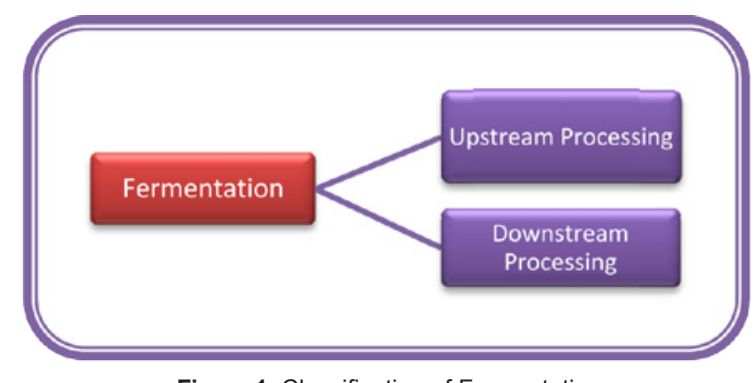

Figure 1: Classification of Fermentation.

*Corresponding author: Sameera V, Biotechnology Department, REVA Institute of Science and Technology, Bangalore University, India, E-mail: sameera vadapalli@yahoo.com

Received March 01, 2011; Accepted April 20, 2011; Published April 28, 2011

Citation: Sameera V (2011) Novel Techniques in the Production of Industrially Imperative Products. J Microbial Biochem Technol R1:003. doi:10.4172/19485948.R1-003

Copyright: (c) 2011 Sameera V. This is an open-access article distributed under the terms of the Creative Commons Attribution License, which permits unrestricted use, distribution, and reproduction in any medium, provided the original author and source are credited 
Citation: Sameera V (2011) Novel Techniques in the Production of Industrially Imperative Products. J Microbial Biochem Technol R1:003. doi:10.4172/1948-5948.R1-003

Page 2 of 9

of biosynthetic products, particularly pharmaceuticals, from natural sources such as animal or plant tissue or fermentation broth, including the recycling of salvageable components and the proper treatment and disposal of waste. Downstream processing and analytical bioseparation both refer to the separation or purification of biological products, but at different scales of operation and for different purposes.

Downstream processing implies manufacture of a purified product fit for a specific use, generally in marketable quantities, while analytical bioseparation refers to purification for the sole purpose of measuring a component or components of a mixture, and may deal with sample sizes as small as a single cell.

A widely recognized heuristic for categorizing downstream processing operations divides them into four groups which are applied in order to bring a product from its natural state as a component of a tissue, cell or fermentation broth through progressive improvements in purity and concentration [6] (Figure 3).

Downstream processing steps mainly involve many techniques such as chromatography, flocculation, crystallization, etc. The rapid development of biotechnology and biomedicine requires more reliable and efficient separation technologies for the isolation and purification of biopolymers such as therapeutic proteins, antibodies, enzymes and nucleic acids [7].

Following are the methods which are used for purification of product [6].
$»$ Filtration
$»$ Centrifugation
» Sedimentation

$»$ Precipitation

» Flocculation

» Adsorption

» Chromatography

$»$ Crystallization

» Fractional distillation

Bioreactors like TOROCELL have also been developed by by Ravindranath Gandlur and Prasadarao Gandlur of Lablinks Biotech Pvt. Ltd. recently for the cultivation of Saccharomyces boulardii as a probiotic supplement, Escherichia coli for plasmid DNA, Streptomyces avidini for producing Streptavidin, BHK 21 [8].

\section{Applications of fermentation}

There is at present a world-wide need to develop the way we handle wastes and to produce energy in a sustainable manner. Taking the waste product of one process and using it as input or fuel for another process is one way to accomplish this by making intelligent use of resources [9]. One such way is fermentation, in which we can use wastes of sugar industry, (molasses) for the production of alcohol. Fermented food and beverages have been used worldwide since time immemorial [10].

Microbial fermentations may be classified into the following major group

(i) Production of microbial cells (biomass) as the product.

(ii) Production of microbial metabolites.

(iii) Production of microbial enzymes.

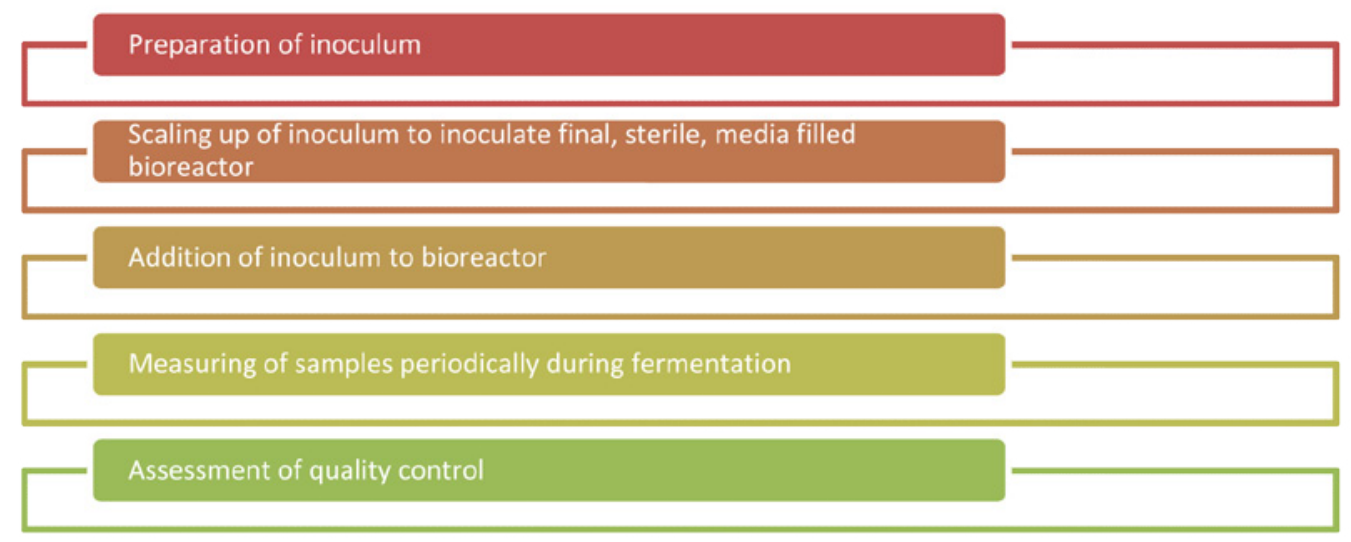

Figure 2: Steps in upstream processing.

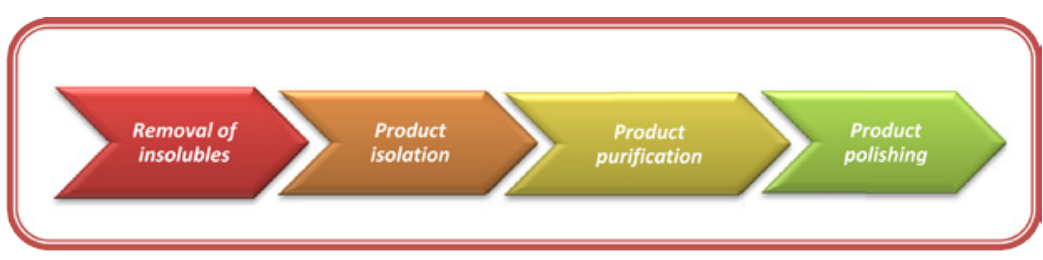

Figure 3: Steps involved in downstream processing. 
Citation: Sameera V (2011) Novel Techniques in the Production of Industrially Imperative Products. J Microbial Biochem Technol R1:003. doi:10.4172/1948-5948.R1-003

Page 3 of 9

(iv) Modification of a compound which is added to the fermentation the transformation processes.

(v) Production of recombinant products [1].

Microbial biomass: Microbial biomass is produced commercially as single cell protein (SCP) for human consumption or animal feed and as viable yeast cells for use in the baking industry.

Microbial metabolites: The metabolism is defined as the sum of all the biochemical reactions carried out by an organism. Primary metabolic pathways converge into few end products while secondary metabolic pathways diverge into many products. Some of these metabolites which are industrially important can be produced by fermentation [11].

E.g. citric acid, alcohols (ethanol using Saccharomyces cerevisiae [12]), etc

Microbial enzymes: Enzymes are biocatalysts produced by living cells to bring about specific biochemical reactions in the cells. Each single strain of organism produces a large number of enzymes, which are hydrolyzing, oxidizing or reducing, and metabolic in nature.

E.g. Lipase [13,72], amylase, glucosidase, penicillinase, Fibrinolytic Enzymes [14], Asparaginase [15-17] etc

In the process of fermentation, selection of strains for the commercial production of specific enzymes is carried out, which have the capacity for producing highest amounts of the enzymes desired. Commercial enzymes are produced from strains of molds, bacteria, and yeasts [18].

Transformation Processes: In some cases of fermentation, microbial cells may be used to catalyse the conversion of a compound into a structurally similar, but financially more valuable, compound. Such fermentations are termed biotransformations, transformation processes, or bioconversions. The reactions that can be catalysed comprise oxidation, dehydrogenation, hydroxylation, dehydration and condensation, decarboxylation, deamination, amination, and isomerization [1].

Recombinant Products: Genes from higher organisms can be introduced into microbial cells for synthesizing foreign (or heterologous) proteins. Examples of the hosts include Escherichia coli, Saccharomyces cerevisiae and other yeasts as well as filamentous fungi such as Aspergillus niger var. awamori. Products produced in such genetically manipulated organisms include interferon, insulin [19], human serum albumin, factor VIII and factor IX, epidermal growth factor, bovine somatostatin and bovine chymosin.

E.g. Production of interferon [20], insulin, human serum albumin, factor VIII and factor IX, epidermal growth factor, bovine somatostatin and bovine chymosin [1], fusion proteins [21], production of antibiotics [22].

Although analysis of select compounds and metabolites has been used broadly to elucidate specific metabolic pathways, it is now more widely being applied to cataloguing all (or most of) the biochemicals coupled with an organism's metabolism (or metabolome) [23]. Analysis of the biochemicals associated with an organism plays a crucial role in selection of strains in fermentation.

A single vertical rotating immobilized cell reactor (VRICR) with the bacterium R. Erythropolis as a biocatalyst, was developed and used for investigation of biodesulfurization procedure with its two consecutive stages of cell growth and desulfurization activity by fermentation [24].

\section{Other applications}

$>$ Production of fermented food [13,25]

> Production of refreshing beverages by the help of "Tea fungus" (kombucha) [26]

$>$ Production of biofuels [27] like ethanol, biogas [28], biomethanol [3]

$>$ Production of pharmacological compounds like salidrosides [29]

$>$ Production of human growth hormones [30,31]

$>$ Production of Bioplastics [23]

$>$ Lipases produced through fermentation are of great importance in food industry in development of flavour esters [32]

$>$ Grapes and apples have been widely applied to ferment beverages [33] the use of other fruits, such as orange [34], cacao [35], mango [36] , gabiroba [37], cajá [38], kiwi [39], and in the production of wine has been recently demonstrated [40].

$>$ Production of mycoprotein [41]

$>$ Production of xylitol [42].

$>$ Ethanol is considered to be the next generation transportation fuel with the most potential, and significant quantities of ethanol are at present being produced from corn and sugar cane by fermentation process [43].

$>$ Production of Pectinmethylesterase by solid state fermentation [44].

In this article, we are going to discuss the fermentation of a range of products which comprise of the following

1. Enzyme production

2. Polysaccharides production

3. Organic acid production

4. Recombinant protein production

\section{Production of enzymes}

Enzymes are among the most significant products obtained for human needs through microbial sources. They are catalysts which speed up a reaction without being used up in the reaction. A large number of industrial processes in the areas of industrial, environmental and food biotechnology utilize enzymes at some stage or the other. Current developments in biotechnology are yielding new applications for enzymes [45]. The starting point for enzyme production is a vial of a selected strain of microorganisms. They will be nurtured and fed until they multiply many thousand times. Then the desired end-product is recovered from the fermentation broth and sold as a standardised product [46].

Different kinds of processes can be used for enzyme production such as, solid state fermentation, submerged fermentation, etc.

E.g. Cellulase (for cellulose hydrolysis), $\beta$-galactosidase (for lactose hydrolysis, which converts lactose to glucose and galactose) [47], 
Citation: Sameera V (2011) Novel Techniques in the Production of Industrially Imperative Products. J Microbial Biochem Technol R1:003. doi:10.4172/1948-5948.R1-003

Page 4 of 9

\section{Cellulase}

Research on cellulase has progressed very rapidly in the past few decades', emphasis being in enzymatic hydrolysis of cellulose to glucose [48]. Cellulose constitutes the highest percentage of municipal and wastes. It represents a major source of renewable energy and raw materials. Therefore, the utilization of cellulosic wastes to produce energy is potentially of great importance [49].

Cellulase refers to a class of enzymes produced primarily by fungi, bacteria, and protozoans that catalyze cellulose hydrolysis (cellulolysis).

Five types of cellulases based on the kind of reaction catalyzed are as follows

1. Endocellulase breaks internal bonds to disrupt the crystalline structure of cellulose and expose individual cellulose polysaccharide chains

2. Exocellulase cleaves two to four units from the ends of the exposed chains produced by endocellulase, resulting in the tetrasaccharides or disaccharides, such as cellobiose. There are two main types of exocellulases [or cellobiohydrolases $(\mathrm{CBH})$ ] - CBHI works processively from the reducing end, and CBHII works processively from the nonreducing end of cellulose.

3. Cellobiase or beta-glucosidase hydrolyses the exocellulase product into individual monosaccharides.
4. Oxidative cellulases depolymerize cellulose by radical reactions, as for instance cellobiose dehydrogenase (acceptor).

5. Cellulose phosphorylases depolymerize cellulose using phosphates instead of water [50].

Method of production: T. reesei is a saprobic fungus capable of efficiently degrading plant cell wall polysaccharides such as cellulose and hemicelluloses. It was first isolated in Solomon Islands in 1944 by the US Army. The original T. reesei isolate, T. reesei QM6a soon became an area of huge interest, due to its high cellulolytic potential. The construction of different mutant strains with several-fold increase in the amount of secreted cellulolytic enzymes compared to the wildtype strain has been achieved by both academic and industrial research programs.

One of the most hypercellulolytic strains, RUT-C30, originated from $T$. reesei QM6a by three rounds of mutagenesis including a UVlight treatment followed by N-nitrosoguanidine (NTG) and another round of UV-light treatments. Recently, massive parallel sequencing of two mutant strains including RUT-C30 and its ancestor NG-14 (originated from T. reesei QM6a) has been reported. Expression of the cellulolytic enzymes in T. reesei is induced by cellulose and also by some disaccharides such as D-lactose, cellobiose and sophorose [51]. Cellulase from $T$. reesei can be produced in following steps [52] (Figure $4)$.

Cellulases are among the industrially important hydrolytic enzymes

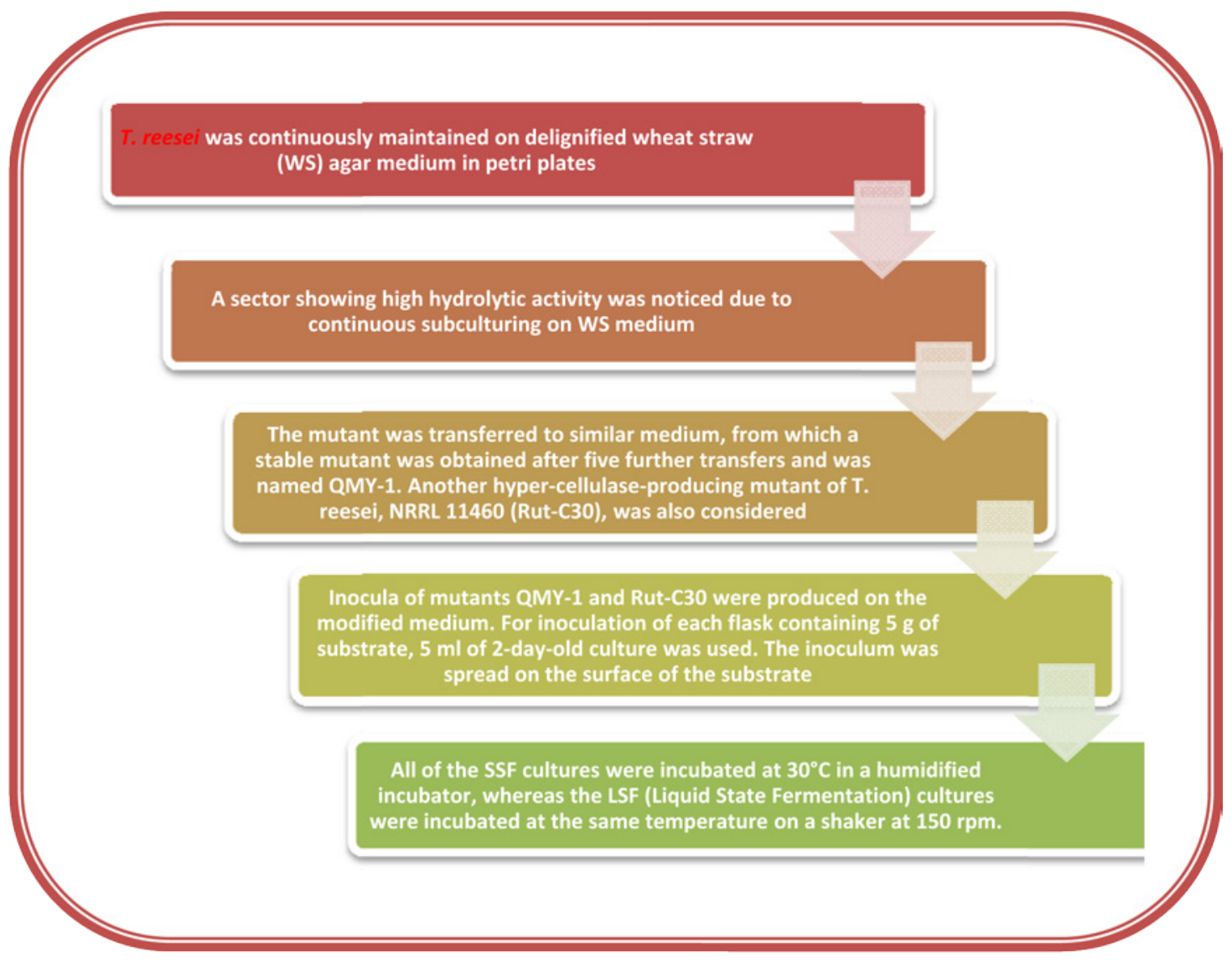

Figure 4: Flow chart for cellulase production by Trichoderma reesei. 
Citation: Sameera V (2011) Novel Techniques in the Production of Industrially Imperative Products. J Microbial Biochem Technol R1:003. doi:10.4172/1948-5948.R1-003

Page 5 of 9

and are of great importance in present day biotechnology. Cellulases are widely used in the food, feed, textile and pulp industries [53].

\section{Production of polysaccharides}

During the past several decades, much interest has been generated in the subject of polysaccharides produced by microorganisms, due to their various biological and pharmacological activities, including immuno-stimulating and anti-tumour activities [54]. Polysaccharides are polymeric carbohydrate structures, formed of repeating units (either mono- or di saccharides) joined together by glycosidic bonds. These structures are often linear, but may contain various degrees of branching.

Bacterial polysaccharides represent a varied range of macromolecules that comprise peptidoglycan, bacterial cellulose [55], lipopolysaccharides, capsules and exopolysaccharides; compounds whose functions range from structural cell-wall components (e.g., peptidoglycan), and chief virulence factors (e.g., Poly-Nacetylglucosamine in S. aureus), in order to permit survival of the bacterium in harsh environments (e.g., Pseudomonas aeruginosa in the human lung). Polysaccharide biosynthesis is a firmly regulated, energyintensive process and understanding the subtle interplay between the regulation and energy conservation is a huge area of research. The potential benefits are huge and should enable the development of novel antibacterial strategies (e.g., new antibiotics and vaccines) and the commercial exploitation to develop novel applications [56].

\section{Exopolysaccharides}

Exopolysaccharides are high molecular weight polymers that are composed of sugar residues and are secreted by a microorganism into the surrounding environment [57]. Microorganisms synthesize a wide range of multifunctional polysaccharides including intracellular polysaccharides, structural polysaccharides and extracellular polysaccharides or exopolysaccharides (EPS). Exopolysaccharides generally consist of monosaccharides and some non-carbohydrate substituents (such as acetate, pyruvate, succinate, and phosphate) [58].

Many dairy lactic acid bacteria which are used for the manufacture of fermented milk products have the ability to produce exopolysaccharides (EPS), which are excreted into the milk during fermentation. They prevent syneresis, and ensure proper texture and body of the end product. Further, it has been reported that EPS isolated from lactic acid bacterial cultures have antitumor activity $[59,60]$. These lactic acid bacteria also play an important role in the biodegradation of azo dyes [61]. In this article, the production of exopolysaccharides from Lactobacillus rhamnosus is discussed.

Method of production: The exopolysaccharide (EPS)-producing cultures such as Lactobacillus rhamnosus RW-9595M present a challenge for the culture producers because the high viscosity of the fermented growth medium make it difficult to recover the cells by centrifugation or filtration [62]. Study has been carried out in order to make it feasible for separation of cells from the culture. Fed-batch culture is observed to be fruitful in this case. Following steps are involved in the production of exopolysaccharides from Lactobacillus rhamnosus

Exopolysaccharide (EPS)-producing lactic acid bacteria (LAB) are of importance to the food industry since they can improve the texture of yoghurts, lower the risk of syneresis and improve yields in cheeses. In addition to their technological benefits, LAB EPS have been recognized to have antitumor, antiulcer and blood cholesterol lowering activities, as well as the capability to enhance the immune system. Therefore EPS-

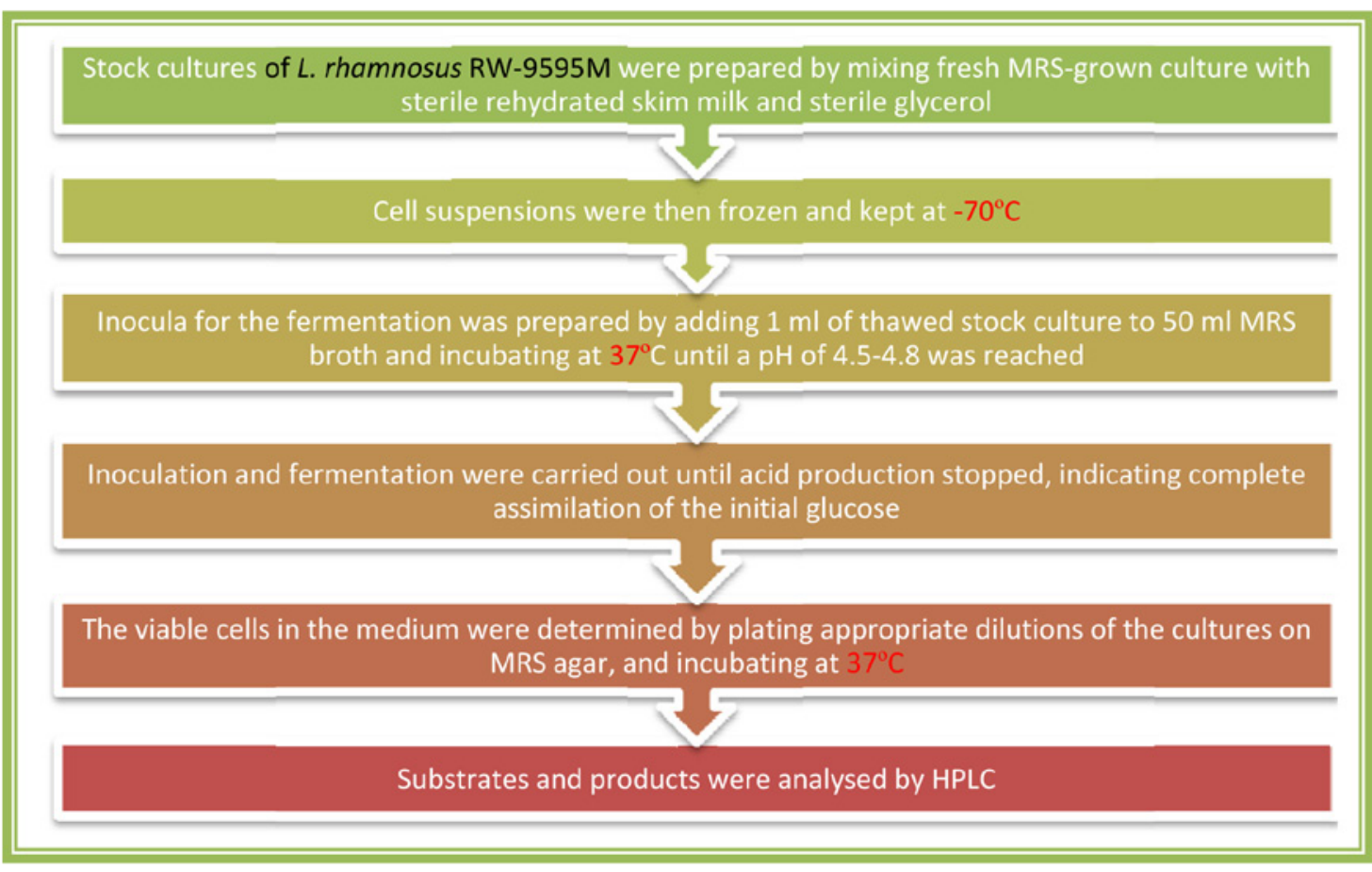

Figure 5: Flow chart of exopolysaccharide synthesis. 
Citation: Sameera V (2011) Novel Techniques in the Production of Industrially Imperative Products. J Microbial Biochem Technol R1:003. doi:10.4172/1948-5948.R1-003

Page 6 of 9

producing strains are of commercial value for both their technological and putative probiotic properties [62] (Figure 5).

\section{Organic acid production}

An organic acid is an organic compound with acidic properties. The most common organic acids are the carboxylic acids, whose acidity is associated with their carboxyl group - $\mathrm{COOH}$. Simple organic acids such as formic or acetic acids are used for oil and gas well stimulation treatments. These organic acids are much less reactive with metals than strong mineral acids like hydrochloric acid $(\mathrm{HCl})$. Therefore, organic acids are used at high temperatures or when long contact times between acid and pipe are needed. The conjugate bases of organic acids such as citrate and lactate are frequently used in biologically-compatible buffer solutions. Biological systems generate many more complex organic acids such as L-lactic, citric, and D-glucuronic acids that contain hydroxyl or carboxyl groups [63].

In this article, recent development in the production of L-Lactic acid is discussed by New Lactobacillus Rhamnosus B 103

Method of production: Interest in the production of L-lactic acid has increased recently due to its capability to serve as raw material for the manufacture of green solvents, such as ethyl lactate and polyL-lactic acid (PLLA). These green solvents are biodegradable and environmentally friendly. PLLA is also biocompatible and can be used in implants, such as scaffolds in humans.

Pure lactic acid in its L-form can be obtained from submerged cultures of Lactobacillus rhamnosus with a simple and low-cost medium. The biotechnological procedures used for production of lactic acid are based on the bioconversion of sugar solutions by bacteria. Both chemical and biotechnological methods are available for manufacture of lactic acid, but biotechnological production offers several advantages over chemical synthesis, such as the low cost of substrates, milder temperature and less energy consumption.
Lactic acid produced through biotechnological fermentation is also preferred for applications in polymer industries due to the prospects of environmental friendliness and the use of renewable sources rather than petrochemicals [64].

Steps involved in the production of lactic acid from Lactobacillus Rhamnosus B 103 are shown in Figure 6. Sugarcane plays a key role in agriculture due to its economic and social importance. Because of its rich composition in fermentable sugars, nitrogenous substances (proteins and amino acids) and vitamins as well as its low cost and high availability, sugarcane juice can be used as a substrate for improving lactic acid production and reducing costs [64].

\section{Recombinant protein production}

Recombinant protein production is the expression of proteins that have been produced by recombinant DNA technology. This process enables these substances to be made in large quantities. Such mass production is done both for laboratory study and for industrial production [65].

High-level production of recombinant proteins as a prerequisite for subsequent purification has become a standard technique. Important applications of recombinant proteins are:

» Immunization,

» Biochemical studies,

» Three-dimensional analysis of the protein, and

»Biotechnological and therapeutic use.

Production of recombinant proteins involves cloning of an appropriate gene into an expression vector under the control of an inducible promoter. But efficient expression of the recombinant gene depends on a variety of factors such as,

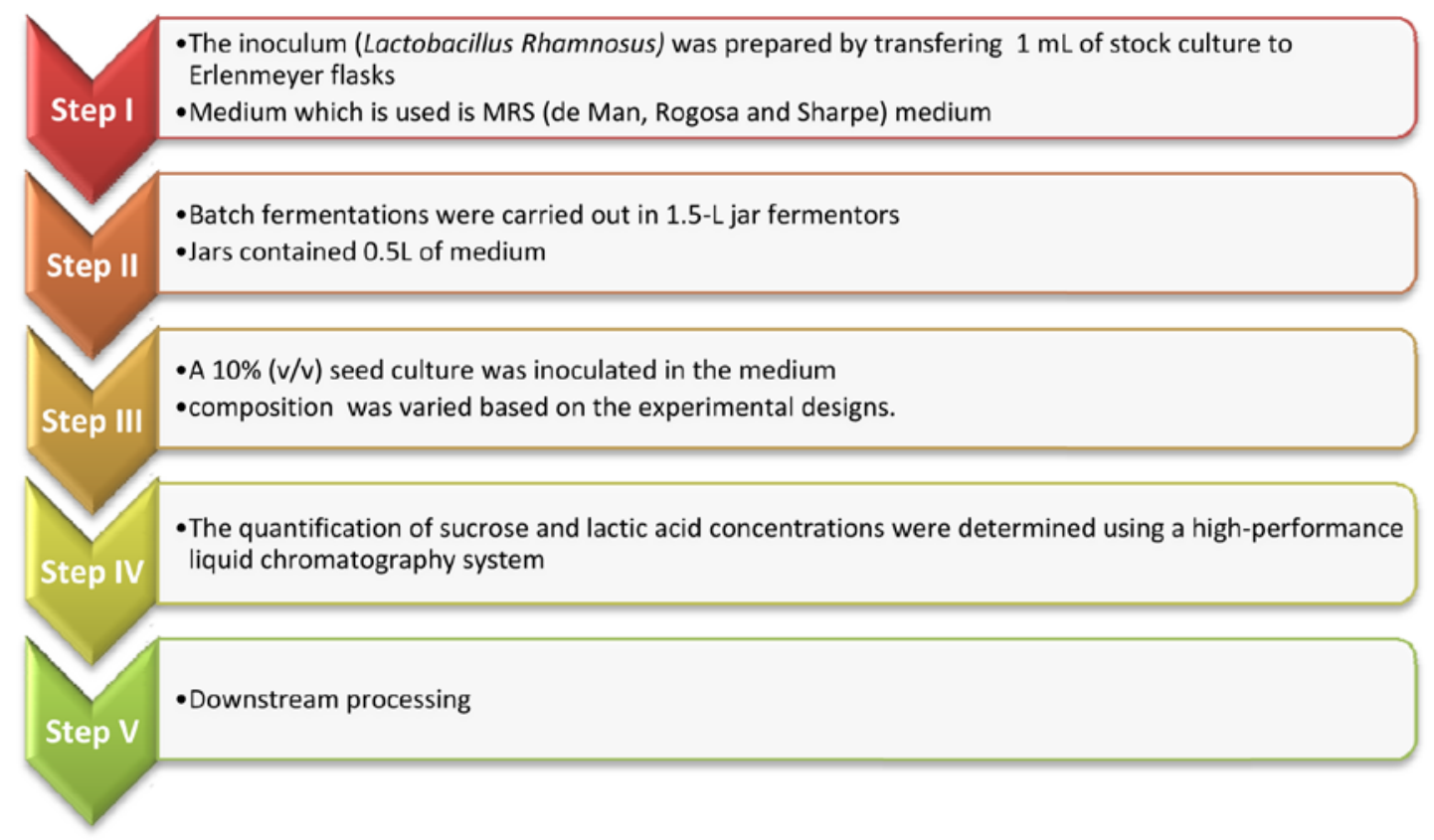

Figure 6: Flowchart for the production of L- lactic acid using Lactobacillus Rhamnosus. 
Citation: Sameera V (2011) Novel Techniques in the Production of Industrially Imperative Products. J Microbial Biochem Technol R1:003. doi:10.4172/1948-5948.R1-003

Page 7 of 9

» Optimal expression signals (both at the level of transcription and translation),

» Correct protein folding and

» Cell growth characteristics [66].

One of such recombinant protein on which research was carried out was Human Interferon $\alpha$.

Human Interferon $\boldsymbol{\alpha}$ : Interferons (IFNs) are natural cell-signalling proteins produced by the cells of the immune system of most vertebrates in response to challenges such as viruses, parasites and tumor cells. Interferon therapy is used (in combination with chemotherapy and radiation) for the treatment for many cancers, AIDS related Kaposi's sarcoma, and chronic hepatitis B and C.

The expression of IFN- $\alpha$ cDNA was achieved directly in E.coli soon after it was first cloned. Since, E. coli could be grown to high cell densities, and strains used for recombinant protein production are generally regarded as safe, it is a preferred expression host for largescale fermentations [67].

Method of production: Currently, Escherichia coli is one of the main scientific subjects not only for basic research but also for applied biotechnology [68]. Process of production of recombinant proteins first involves the construction of gene which codes for the protein, amplification of that gene, transformation into suitable host (E.Coli), growing the colonies on the medium, and then purification of protein. It involves the following steps [67].

IFNa2b gene was amplified in PCR using the forward primer 5'CCG CCG GGA TCC GAT GAT GAT GAT AAA TGT GAC CTA CCA CAA ACC CAC 3' that introduces a BamH1 site at the 5' end of the gene and a reverse primer 5' CCG CCG GAA TTC AAG CTT TCA TTA CTC TTT AGA TCT TAA 3'containing the EcoR1 site at the 3' end of the gene

$>$ The ligation mix was then introduced into DH5a competent cells

$>$ Recombinant clones were screened by colony using IFN gene specific primers.

$>$ The PCR positive clones were later selected by restriction digestion and the selected clone was designated as pET21a-IFN

$>$ SAK gene was PCR amplified from the synthetic gene using 5' CCG CCG GAA TTC CAT ATG TCA TTC GAC AAA GGA 3' and 5' CCG CCG GAA TTC TTA TTT ATC ATC ATC ATC GGA TCC TTT CTT TTC TAT AAC AAC 3' as the forward and reverse primer respectively.

(SAK will have enterokinase (DDDDK) recognition site.)

$>$ The ligation mix was used for transformation of DH5a cells

$>$ Colonies were screened with colony PCR for SAK gene using gene specific primers.

$>$ The clones were further confirmed by restriction analysis NdeI/ EcoRI digestion.

$>$ The construct was designated as pET21a-SAK-IFN

$>$ BL21A1 cells and BL21(DE3) codon plus cells were independently transformed using pET21a- IFN and pET21aSAKIFN plasmids.
$>$ The cultures were then inoculated into Luria Bertani (LB) with ampicillin at $100 \mu \mathrm{g} / \mathrm{ml}$ and incubated at $37^{\circ} \mathrm{C}$ till $\mathrm{A} 600 \mathrm{~nm}$ was nearly 0.5 to 0.6 .

> The cells were induced with $13 \mathrm{mM}$ arabinose and $1 \%$ lactose in case of BL21A1 cells while $1 \mathrm{mM}$ IPTG was used in case of BL21(DE3) codon plus cells.

$>$ Cells were pelleted, lysed with glass beads and the soluble and insoluble cell fractions were separated

S Suitable aliquots of both the soluble and insoluble fraction were checked for expression on 12\% SDS-PAGE gel followed by silver stain.

$>$ Purification of the protein [67].

IFN fusion proteins have been created to render them soluble in E. coli. Some of the well studied interferon fusions include GST-IFN [69], HSA-IFN [70] and the latest report on the fusion of IFN with the antimicrobial peptide as IFN-CM4 fusion [71].

Nowadays there is a rising interest in the development of more efficient and less time-consuming methods to assess the presence of microbes, as well as their viability for bioprocess control and improvement. Rapid detection of microorganisms in samples is one of the important questions to obtain real-time data for the development of more precise quality control programs, but also for monitoring microbial population during fermentation stages, in order to achieve a better control over processes [73]. Identifications of microbial organisms are now usually done by comparing their SSU rRNA gene sequences to those of known organisms. The standard application is to study the composition of the microbial community within a given environmental or clinical sample [74]. Metabolic profiling is one method which can be used for cataloguing all (or most of) the biochemicals associated with an organism's metabolism [75].

\section{Conclusion}

Fermentation and production of industrially important products involves crucial steps to be followed aseptically. Fermentation is more than 3000 years old and since then, many developments have been made and many implications have been drawn in development of novel techniques for more enhanced improved production of industrially important products. Some of those techniques have been discussed in this review with regard to the production of lactic acid, cellulase, exopolysaccharide, and human hormones. These techniques involved improved strategies like using genetically engineered microbes, and new methodologies which resulted in high yield and cost effective production of these products.

\section{References}

1. Stanbury PF, Hall SJ, Whitaker A (1998) Principles of fermentation technology, Pergamon Press, Oxford, 1995

2. Jung EY, Lee HS, Seo HC, Suh HJ (2010) Safety Evaluation of Yeast Hydrolysate (Notress). J Microbial Biochem Technol 2: 58-63.

3. Iyovo GD, Du G, Chen J (2010) Sustainable Bioenergy Bioprocessing Biomethane Production, Digestate as Biofertilizer and as Supplemental Feed in Algae Cultivation to Promote Algae Biofuel Commercialization. J Microbial Biochem Technol 2: 100-106.

4. http://www.bio-link.org/GMP/Section_1_6_0.html

5. Lee T, Amore TD (2011) Membrane Separation Theoretical and Applicable Considerations for Optimum Industrial Bioprocessing. J Bioprocess Biotechniq 1: $101 \mathrm{e}$ 
Citation: Sameera V (2011) Novel Techniques in the Production of Industrially Imperative Products. J Microbial Biochem Technol R1:003. doi:10.4172/1948-5948.R1-003

6. http://en.wikipedia.org/wiki/Downstream_processing

7. Miyauchi M, Miao J, Simmons TJ, Dordick JS, Linhardt RJ (2011) Flexible Electrospun Cellulose Fibers as an Affinity Packing Material for the Separation of Bovine Serum Albumin. J Chromatograph Separat Techniq 2: 110.

8. Prasadarao G (2011) TOROCELL- disposable bioreactor system and its applications. J Microbial Biochem Technol. World congress on Biotechnology, India

9. Iyovo GD, Du G, Chen J (2010) Sustainable Bioenergy Bioprocessing: Biomethane Production, Digestate as Biofertilizer and as Supplemental Feed in Algae Cultivation to Promote Algae Biofuel Commercialization. J Microbial Biochem Technol 2: 100-106.

10. Shukla P, Vishwakarma P (2011) Biochemical and Microbial Examination of Sulphi and Cheend: Two Alcoholic Beverages from Central India. J Nutr Food Sci 1: 105

11. Jemma K \& Emma O'Leary , Primary Versus Secondary Metabolites of Microorganisms

12. Benerji DSN, Ayyanna C, Rajini K, Rao BS, Banerjee DRN, et al. (2010) Studies on Physico-Chemical and Nutritional Parameters for the Production of Ethanol from Mahua Flower (Madhuca indica) Using Saccharomyces Cerevisiae 3090 Through Submerged Fermentation (smf). J Microbial Biochem Technol 2: 46-50.

13. Dajanta K, Apichartsrangkoon A, Chukeatirote E (2011) Antioxidant properties and total phenolics of thua nao (a Thai fermented soybean) as affected by Bacillus-fermentation. J Microbial Biochem Technol 3: 56-59.

14. Gesheva V (2009) Production of Fibrinolytic Enzyme by Streptomyces Rimosus at Conditions of Nitrogen Limitation. J Microbial Biochem Technol 1: 57-58.

15. Vuddaraju SP, Nikku MY, Chaduvula AIR, Dasari VRRK, Donthireddy SRR (2010) Application of Statistical Experimental Designs for the Optimization of Medium Constituents for the Production of L-Asparaginase by Serratia Marcescens. J Microbial Biochem Technol 2: 89-94.

16. Karanam SK, Medicherla NR (2010) Application of Doehlert experimental design for the optimization of medium constituents for the production of L-asparaginase from Palm Kernal cake (Elaeis guineensis). J Microbial Biochem Technol 2: 7-12.

17. Wink PL, Bogdawa HM, Renard G, Chies JM, Basso LA, et al. (2010) Comparison between Two Erwinia carotovora L-Asparaginase II Constructions: cloning, Heterologous Expression, Purification, and Kinetic Characterization. J Microbial Biochem Technol 2: 13-19.

18. Underkofler LA, Barton RR, Rennert SS (1957) Production of Microbial Enzymes and Their Applications

19. Kuric $L$ (2011) Molecular Biocoding of Insulin - Amino Acid Ser. J Bioengineer \& Biomedical Sci 1: 102

20. Villela AD, Renard G, Palma MS, Chies JM, Dalmora SL (2010) Human Interferon B1ser17: Coding DNA Synthesis, Expression, Purification and Characterization of Bioactive Recombinant Protein. J Microbial Biochem Technol 2: 111-117.

21. Das KMP, Barve S, Banerjee S, Bandyopadhyay S, Padmanabhan S (2009) A Novel Thermostability Conferring Property of Cherry Tag and its Application in Purification of Fusion Proteins. J Microbial Biochem Technol 1: 59-63.

22. Burdock TJ, Brooks MS, Ghaly AE (2010) A Dehydrogenase Activity Test for Monitoring the Growth of Streptomyces Venezuelae in a Nutrient Rich Medium J Bioprocess Biotechniq 1: 101

23. Porta R, Di Pierro P, Sorrentino A, Mariniello L (2011) Promising Perspectives for Transglutaminase In "Bioplastics" Production. J Biotechnol Biomaterial 1: $102 \mathrm{e}$.

24. Amin GA (2011) Integrated Two-Stage Process for Biodesulfurization of Model Oil by Vertical Rotating Immobilized Cell Reactor with the Bacterium Rhodococcus erythropolis. J Pet Environ Biotechnol 2: 107.

25. Ukuku D, Yuk HG, Zhang H (2010) Behavior of Pulsed Electric Fields Injured Escherichia coli O157:H7 Cells in Apple Juice Amended with Pyruvate and Catalase. J Microbial Biochem Technol 2: 134-138.

26. Santos RJ Jr, Batista RA, Rodrigues SA, Filho LX, Lima AS (2009) Antimicrobial Activity of Broth Fermented with Kombucha Colonies. J Microbial Biochem Technol 1: 72-78.
27. Iyovo GD, Du G, Chen J (2010) Poultry Manure Digestate Enhancement of Chlorella Vulgaris Biomass Under Mixotrophic Condition for Biofuel Production. J Microbial Biochem Technol 2: 51-57.

28. Daisy A (2011) The Impact and Treatment of Night Soil in Anaerobic Digester: A Review. J Microbial Biochem Technol 3: 43-50.

29. Jiang-ning Al, Bin Z, Jing-ming JIA (2009) The Effects of NO and AgNO3 on Cell Growth and Salidroside Synthesis in Rhodiola sachalinensis A.Bor. Cell Suspension Culture. J Microbial Biochem Technol 1: 11-14

30. Soorapaneni S, Apte-Deshpande A, Prasad SK, Kumar J, Raiker VA, et al. (2010) Arabinose Promoter Based Expression of Biologically Active Recombinant Human Growth Hormone in E. coli: Strategies for Over Expression and Simple Purification Methods. J Microbial Biochem Technol 2: 38-45.

31. Jensen EB, Carlsen S (1990) Production of recombinant human growth hormone in Escherichia coli: expression of different precursors and physiological effects of glucose, acetate, and salts. Biotechnol Bioeng 36: 1-11

32. Syamsul KMW, Salina MR, Siti Salhah O, Hanina MN, Mohd Basyaruddin AR (2011) Optimization of Lipase Catalyzed Synthesis of Nonyl Caprylate using Response Surface Methodology (RSM). J Biotechnol Biomaterial 1:106.

33. Polychroniadou E, Kanellaki M, Iconomopoulou M, Koutinas AA, Marchant R et al. (2003) Grape and apple wines volatile fermentation products and possible relation to spoilage. Bioresource Technology 87: 337-339.

34. Selli S, Canbas A,Varlet V, Kelebek H, Prost C, et al. (2008) Characterization of the most odor-active volatiles orange wine made from a Turkish cv. Kozan (Citrussinensis L. Osbeck). J Agric Food Chem 56: 227-234.

35. Dias DR, Schwan RF, Freire ES, Serôdio RD (2007) Elaboration of a fruit wine from cocoa (Theobroma cacao L.) pulp. International Journal of Food Science \& Technology 42: 319-329.

36. Kumar YS, Prakasam RS, Reddy OVS (2009) Optimization of fermentation conditions for mango (Mangifera indica L.) wine production by employing response surface methodology. International Journal of Food Science \& Technology 44: 2320-2327.

37. Duarte WF, Dias DR, Pereira GVM, Gervásio IM, Schwan RF (2009) Indigenous and inoculated yeast fermentation of gabiroba (Campomanesia pubescens) pulp for fruit wine production. J Ind Microbiol Biotechnol 36: 557-569.

38. Soufleros EH, Pissa P, Petridis D, Lygerakis M, Mermelas K, et al. (2001) Instrumental analysis of volatile and other compounds of Greek kiwi wine sensory evaluation and optimisation of its composition. Food Chemistry 75 487-500.

39. Duarte WF, Dias DR, Oliveira JM, Teixeira JA, Silva JBA, et al. (2010) Characterization of different fruit wines made from cacao, cupuassu, gabiroba jabuticaba and umbu. LWT Food Science and Technology 43: 1564-1572.

40. Sevda SB, Rodrigues L (2011) Fermentative Behavior of Saccharomyces Strains During Guava (Psidium Guajava L) Must Fermentation and Optimization of Guava Wine Production. J Food Process Technol 2:118.

41. Hosseini SM, Khosravi-Darani K (2010) Response Surface Methodology for Mycoprotein Production by Fusarium Venenatum ATCC 20334. J Bioprocess Biotechniq 1: 102

42. Mueller M, Wilkins MR, Banat IM (2011) Production of Xylitol by the Thermotolerant Kluyveromyces marxianus IMB Strains. J Bioprocess Biotechniq 1: 102e

43. Zhang B, Shahbazi A (2011) Recent Developments in Pretreatmen Technologies for Production of Lignocellulosic Biofuels. J Pet Environ Biotechnol 2: 108.

44. Gayen S, Ghosh U (2011) Pectinmethylesterase Production from mixed agro- wastes by Penicillium notatum NCIM. 923 in Solid-State fermentation. J Bioremed Biodegrad 2: 119.

45. Ashok P, Selvakumar P, Carlos RS, Poonam N (1999) Solid State Fermentation for The Production of Industrial Enzymes. Current science 77: 149-162

46. http://www.mapsenzymes.com/Making_of_Enzymes.asp

47. Pakizeh M, Namvar-Mahboub M (2011) Experimental Study of Lactose Hydrolysis and Separation in Continuous Stirred Tank -Ultrafiltration Membrane Reactor. J Chem Eng Process Technol 2: 110. 
Citation: Sameera V (2011) Novel Techniques in the Production of Industrially Imperative Products. J Microbial Biochem Technol R1:003. doi:10.4172/1948-5948.R1-003

Page 9 of 9

48. Sravani M, Sirisha Ch, Sri Rami reddy D, Yugandhar NM (2011) Production of cellulase by Cellulomonas uda using banana fruit stalk under Solid substrate fermentation. J Biotechnol Biomater. World congress on Biotechnology, India

49. El-Bondkly AM, Aboshosha AAM, Radwan NH, Dora SA (2010) Successive Construction of $\beta$-Glucosidase Hyperproducers of Trichoderma Harzianum Using Microbial Biotechnology Techniques. J Microbial Biochem Technol 2: 70-73.

50. http://en.wikipedia.org/wiki/Cellulase

51. Mehdi D, Robert B, Wensheng Q (2011) Effect of different carbon sources on cellulase production by Hypocrea jecorina (Trichoderma reesei) strains. Int $\mathrm{J}$ Biochem Mol Biol 2: 274-286.

52. Chahal DS (1984) Solid-State Fermentation with Trichoderma reesei for Cellulase Production. Appl Environ Microbiol 49: 205-210

53. Gilna VV, Khaleel KM (2011) Cellulase Enzyme Activity of Aspergillus Fumigatus from Mangrove Soil on Lignocellulosic Substrate. Recent Research In Science And Technology 3: 132-134

54. Beshay U, Daba A, Gohar Y (2009) Optimization of submerged culture conditions for exo-polysaccharides production by Streptomyces nasri-UV 135 in bioreactor. J Microbial Biochem Technol 1: 43-46.

55. Hungund BS, Gupta SG (2010) Improved Production of Bacterial Cellulose From Gluconacetobacter persimmonis GH-2. J Microbial Biochem Technol 2 127-133

56. http://en.wikipedia.org/wiki/Polysaccharide

57. Shukla P, Patel N, Mohan Rao R, Shukla J, Verma S, et al. (2011) Isolation and characterization of polyhydroxyalkanoate and exopolysaccharide producing Bacillus sp. PS1 isolated from sugarcane field in Bhilai, India. J Microbial Biochem Technol 3: 33-35.

58. http://en.wikipedia.org/wiki/Exopolysaccharide

59. Cerning J, Renard CMGC, Thibault JF, Bouillanne C, Landon M ,et al. Carbon Source Requirements for Exopolysaccharide Production by Lactobacillus case CG11 and Partial Structure Analysis of the Polymer. Appl Envir Microbiol 60: 3914 - 3919.

60. Beshay U, Daba A, Gohar Y (2009) Optimization of submerged culture conditions for exo-polysaccharides production by Streptomyces nasri-UV 135 in bioreactor. J Microbial Biochem Technol 1: 43-46.

61. Elbanna K, Hassan G, Khider M, Mandour R (2010) Safe Biodegradation of Textile Azo Dyes by Newly Isolated Lactic Acid Bacteria and Detection of Plasmids Associated With Degradation. J Bioremed Biodegrad 1:112.

62. Claude P, Champagne, Nancy JG, Christophe L (2007) Fermentation technologies for the production of exopolysaccharidesynthesizing Lactobacillus rhamnosus concentrated cultures. Electronic Journal of Biotechnology 10: 211 220 .

63. http://en.wikipedia.org/wiki/Organic_acid.

64. de Lima CJB, Coelho LF da Silva GP, Alvarez G, Contiero J (2010) L(+) Lactic Acid Production by New Lactobacillus Rhamnosus B 103. J Microbial Biochem Technol 2: 64-69.

65. http://www.wisegeek.com/what-is-recombinant-protein-production.htm

66. Wolfgang S, Ferreira LC (2004) Production of recombinant proteins in Escherichia coli. Genet Mol Biol 27: 442-453.

67. Salunkhe SS, Prasad B, Sabnis-Prasad K, Apte-Deshpande A, Padmanabhan S (2009) Expression and Purification of SAKfused Human Interferon Alpha in Escherichia coli. J Microbial Biochem Technol 1: 5-10.

68. Eremina NS, Yampolskaya TA, Altman IB, Mashko SV, Stoynova NV (2010) Overexpression of ydbK-encoding Putative Pyruvate Synthase Improves L-valine Production and Aerobic Growth on Ethanol Media by an Escherichia coli Strain Carrying an Oxygen-Resistant Alcohol Dehydrogenase. J Microbia Biochem Technol 2: 77-83.

69. Rabhi-Essafi I, Sadok A, Khalaf N, Fathallah DM (2007) A strategy for highlevel expression of soluble and functional interferon alpha as a GST fusion protein in E. coli. Protein Eng Des Sel 20: 201-209.

70. Zhao HL, Xue C, Wang Y, Li XY, Xiong XH, et al. (2007) Circumventing the heterogeneity and instability of human serum albumin-interferon-a2b fusion protein by altering its orientation. J Biotechnol 131: 245-252.

71. Li NN, Liu P, Chen SJ, Zhou LF, Zhang SQ (2009) Construction and expression of a novel bioactive IFN-alpha2b/CM4 fusion protein in E. coli. Microbiol Res (Epub, ahead of Print)

72. Imandi SB, Karanam SK, Garapati HR (2010) Optimization of Process Parameters for the Production of Lipase in Solid State Fermentation by Yarrowia lipolytica from Niger Seed oil Cake (Guizotia Abyssinica). J Microbial Biochem Technol 2: 28-33.

73. da Silva TL, Feiião D, Reis A (2011) Monitoring Rhodotorula glutinis CCMI 145 Stress Physiological Response during Fed-Batch Fermentations Using MultiParameter Flow Cytometry. J Microbial Biochem Technol 3: 6-12.

74. Croce O, Chevenet F, Christen R (2010) A New Web Server for the Rapid Identification of Microorganisms. J Microbial Biochem Technol 2: 84-88.

75. Denery JR, Cooney MJ, Li QX (2011) Diauxic and Antimicrobial Growth Phase of Streptomyces Tenjimariensis: Metabolite Profiling and Gene Expression. J Bioengineer \& Biomedical Sci 1:101. 